\title{
Memberdayakan Partai Politik dalam Era Multipartai
}

\author{
Bambang Cipto
}

The adaption of Multiparty. System has been considered to be the best way to reach Democracy. This writing has been based on standardized theoritical assumptions and on empirical experiences of some particular countries ini applying the Multiparty System. At the same token, this article also provides a more comprehensive answer about the prospect as well as the threat faced by the system. This article has not merely based on the dream of developed countries applying the system for relatively long time.

ejak sistem multipartai kembali diberlakukan muncul berbagal apresiasii teriadap prospek dan tantangan sistem partai tersebut. Kesan pertama yang segera muncul adalah bahwa sistem tersebut pemah diterapkan dalam dekade 50-an tetapi gagal di tengah jalan. Bahkan setelah berjalan hampir satu tahun kesan negatif itu, masih cukup. kuat disebagian lapisan masyarakat. Banyaknya partai yang bermunculan dengan berbagai aneka ragam tanda gambar, tidak jarang beberapa partail menggunakan tanda gambar yang mirip satu sama lain, membuat kesan negatif tersebut semakin kuat.

Sebaliknya bagi para aktifis partai-partai politik baru yang muncul secara mendadak maupun yang sudah cukup lama mempersiapkan diri sistem multipartai mereka anggap sebagai penuh harapan dan tantangan. Mereka pada umumnya sangat percaya bahwa inilah sistem partal yang paling tepat bagi Indonesia setelah leblh darii 30 tahun hidup dibawah sistem partai dominan. Tidak heran bila peserta pemilu yang dianggap sah oleh Komisi Pemilihan Umum jumlahnya mencapai 48 partai politik. Se- buah jumlah yang luar biasa besar bahkan bagi negara berkembang sekalipun.

Akan tetapi mengingat pengalaman Orde Baru yang sangat menentang pembentukan partal baru maka tidak mengherankan jika pandangan positiplah yang hingga kini tetap kuat bertahan. Dalam arti bahwa sistem multipartai relatif didukung oleh sebagian besar masyarakat politik walaupun bukan tanpa kritik sama sekali. Dikalangan mahasiswa tidak jarang muncul berbagai pandangan sinis terhadap partai-partai politik yang dianggap lebih banyak melakukan deklarasi daripada melakukan pendidikan politik.

Tudingan ini cukup serius karena muncul dari lapisan mahasiswa yang akhir-akhir ini dikenal sebagai pasukan reformasi yang selalu berada digaris depan dalam menyuarakan perubahan-perubahan politik. Sekalipun demikian tulisan ini akan mencoba memberikan jawaban lebih komprehensif berkenaan dengan prospek dan tantangantantangan yang akan dihadapi oleh sistem multipartai ditengah upaya bangsa ini menuju Indonesia baru di masa depan. Tulisan ini akan dibangun berdasarkan 
asumsi-asumsi teoritis baku dan pengalaman empiris sistem multipartai di berbagai negara-negara transisi. Dengan menggunakan kedua perspektif ini diharapkan agar visi dari karya tulis ini tidak semata-mata dibangun di atas impian negara-negara industri maju yang telah cukup lama menerapkan sistem multipartai. la dengan sendirinya juga akan diwamai oleh pelajaran tentang upaya tiada henti dari negara-negara demokrasi baru dengan berbagai kompleksitas permasalahannya.

Secara teoritis sistem multipartai bisa dikatakan sangat sesuai dengan kondisi objektif bangsa Indonesia yang sangat heterogen dengan berbagal perbedaan budaya, agama, suku, bahasa, golongan dan kedaerahan. Arend Lijphart, misalnya, membuat sebuah asumsi yang cukup valid bahwa untuk masyarakat-rnasyarakat dengan tingkat pluralisme yang cukup tinggi sistem partai yang diterapkan pada umumnya adalah sistem multipartai. Alasan yang dikemukakan adalah masyarakat plural dibutuhkan lebih banyak partai yang terwakili badan legislatif agar kelompokkelompok minoritas tidak tertindas. Sistem partai pada masyarakat plural dengan sendirinya bersifat multidimensional. Sementara untuk masyarakat-masyarakat yang relatif homogen maka sistem dua partai jauh lebih tepat untuk diterapkan. ${ }^{1}$

Berdasarkan asumsi diatas maka jelas bahwa sistem multipartai jauh leblh tepat bagi Indonesia daripada sistem dua partai. Kegagalan Orde Baru membangun sebuah partai dominan dan dua partai omamen merupakan bukti kegagalan visi politik rejim Orde Baru dalam membangun sistem partai yang responsif terhadap tuntutan objektif masyarakat plural Indonesia.

Sekalipun demikian eksperimen bangsa Indonesia dengan sistem multipartai terbaru ini dihadapkan pada sebuah dilema yang cukup pelik. Di satu pihak, sistem multipar- tai ini masih berada dalam tahap pertumbuhan awal sehingga bersifat lemah dan rentan terhadap gangguan eksternal. Sistem multipartai pada hakekatnya belum sepenuhnya mendapat legitimasi dari masyarakat politik. Di pihak lain, ABRI sebagai kekuatan sosial-politik hingga kini masih berada pada posisi menentukan dalam sistem politik dan setiap saat dapat meruntuhkan pondasi baru sistem multipartai muda ini sebagaimana pada eksperimen multipartal pertama dalam dekade 50-an yang lampau.

Sifat kemudaan dari sistem multipartai ini perlu mendapat perhatian serius dari semua pihak agar dimasa depan tidak mudah dikecewakan oleh penampilan yang kurang sempuma dari sistem partai baru ini. Sekalipun demikian dengan memasukkan unsur militer dalam analisis ini menjadi jelas bahwa proses pertumbuhan sistem multipartai ini bukan hanya baru sifatnya namun juga transisional menuju sistem politik bebas carnpur tangan militer. Dalam konteks inilah sebenarnya sistem multipartai dapat kita pahami secara lebih komprehensif dengan mengajukan berbagai persoalan-persoalan yang ada dan yang akan muncul di masa depan kemudian mencari solusi jangka pendek dan jangka panjang dalam konteks pembangunan Indonesia baru.

\section{Paradok-paradok Sistem Multipartai}

Berdasarkan studi sejarah kepartaian pertumbuhan sistem multipartai dapat dibagi ke dalam dua bagian sentral. ${ }^{2}$ Baglan

' Arend Lijphart, Democracies.. Pattems of Majoritarian and Comensus, Govemment in Twenty-one Countries, New Haven: Yale University Press, 1984, ha]. 27.

2 Timothy J. Power, "Puppets, Parties, and Paradoxs: Changing Attitude Toward Party Institutionalization" Party Politics, Vol. 3, (April, 1997), hal. 207. 
pertama mencakup pertumbuhan dan perkembangan sistem multipartai yang dipenuhi dengan uji-coba dalam segala aspeknya. Pada tahap pertama ini jumlah partai pada umumnya sangat besar sebaga! akibat dari ledakan partisipasi politik. Tahapan pertama ini cukup rentan terhadap manuver politik militer sebagai akibat dari konflik yang mudah terbangun sebagai akibat persaingan keras dengan partai-partai baru termasuk didalamnya partal-partai status quo yang masih ingin tetap mempertahankan kekuasaannya. Ramifikasi konflik ini membuat partai-partai kehilangan kesempatan untuk melembagakan nilai-nilai dasamya sehingga sulit tampil sebagai partal dalam arti sebenamya.

Bagian kedua dari perkembangan sistem multipartai adalah pada saat partai-partai sudah mulai melembagakan diri yang dengan sendirinya membuat sistem kepartaian pun terlembaga pula. Diperlukan waktu cukup lama untuk menuju sistem multipartai yang terlembaga apalagi jlka sistem partai dominan pemah lama mendominasi sistem kepartaian ditambah dengan faktor militer didalamnya. Tahapan kedua ini muncul jika berbagal permasalahan dalam periode pertama sudah mulai dapat ditangani oleh partai-partai baru.

Pada tahapan pertama pertumbuhan sistem multipartal dapat diidentifikasi beberapa permasalahan pokok partai, antara lain, tidak adanya ikatan kohesif dalam tubuh partai. Hubungan antara elit dan massa masih terlalu renggang. Kalaupun ada sifatnya sangat cair karena dibangun dalam waktu singkat dan penuh dengan karakter emosional. Masing-masing faksi dalam tubuh partai baru mengklaim sebagai pendukung pimpinan puncak atau tokoh senior partai dan berusaha menduduki posisi strategis partal. Akibatnya banyak politisi baru yang benar-benar tidak berpengalarnan menduduki posisi-posisi penting dan menen- tukan padahal mereka belum sepenuhnya siap. Dapat dikatakan bahwa partai-partai baru sering kekurangan politisi professional dan kelebihan politisi yang kurang atau bahkan sama sekali tidak profesional,

Nominasi calon anggota legislatif adalah persoalan lain mengingat ketiadaan kriteria yang jelas. Kelangkaan kriteria ini memicu persaingan antar faksi dalam tubuh partai dan tidak jarang diakhlri dengan konflik membara dan bukan tidak mungkin perpecahan partai. Faksi-faksi itu, antara lain, adalah mereka yang merasa sangat aktif dalam organisasi politik baru ini, kelompok pembèri sumbangan terbanyak, kelompok sangat dekat dengan elit partal, atau dari faksi terbesar. Mereka bersaing ketat untuk mendapatkan jatah dalam nominasi anggota legislatif

Karena rekruitmen caleg tidak berlangsung sempurna maka sulit mengharapkan bahwa partai-partai akan memainkan peran yang sempurna dalam badan legislatif.Menurut Power badan legislatif yang dihasilkan oleh sistem multipartai pada tahapan awal ini akan ditandai dengan situasi fragmentatif. Kondisi ini sangat tidak. menguntungkan bagi partal-partai untuk membangun koalisi karena koalisi menuntut partal-partai yang kohesif dan otonom. Jika berbedaan faksional dalam tubuh partai terbawa ke badan legislatif maka partai-partal akan sulit bekerja-sama satu sama lain.

Sebuah contoh spektakuler adalah eksperimen multipartai di Jepang. Sudah cukup lama. Jepang memiliki sistem multipartai namun selama 36 tahun LDP selalu unggul dalam setiap pemilihan. Akibatnya badan legislatif Jepang selama tiga setengah dasawarsa selalu dikuasai partai dominan LDP. Aǩan tetapi kasus korupsi yang berpuluh tahun menyelimuti LDP akhimya membuat partai ini terjungkal untuk pertama kalinya dalani pemilu 1993. Diluar du- 
gaan semua orang, temyata partai-partai baru yang bergabung mengalahkan LDP ternyata tidak dapat bertahan lama dan sudah dua tahun terakhir ini LDP kembali menguasai parlemen Jepang. Sementara di Brasil dibutuhkan hingga lebih dari tiga putaran pemilu reformasi sebelum partai oposisi benar-benar memiliki kesempatan untuk mendominasi parlemen Brasil. Bila di Jepang partai oposisi gagal bertahan di kursi kekuasaan, maka di Brasil membutuhkan waktu yang cukup lama untuk mendominasi parlemen dan eksekutif

Kedua contoh diatas secara empirik menunjuk pada gejala pertumbuhan awal sistem multipartai yang penuh dengan resiko dan tantangan serius. Ketidaksiapan partai-partai baru bisa berakibat fatal, yakni, muncuinya kembali partai status quo atau lambatnya proses reformasi. Diperlukan kemámpuan tinggi di kalangan elit partai-partai baru untuk dapat membaca dan mengantisipasi paradok-paradok sistem multipartai agar tidak terjebak ke dalam bahaya laten kelompok anti-reformis.

\section{Mencari Budaya Koalisi}

Transisi menuju sistem multipartai bukan sekedar gejala perubahan jumlah partai dan aturan main politik ia juga seharusnya ditkuti oleh perubahan budaya politik, khususnya budaya berkoalisi antar partai. Bangsa ini pemah mencoba meletakkan dasar-dasar budaya koalisi pada dekade 50an melalui serangkaian eksperimen koalisi beberapa partai. Namun eksperimen tersebut berakhir gagal karena dua hal. Pertama, koalisi dimasa lalu dilakukan dengan tidak memperhatikan karakter dasar masing-masing partai. Persoalan ini membuat partajpartai politik dengan basis aliran berbeda bahkan "sebenarnya" bertentangan secara ideologis kemudian bergabung membentuk pemerintahan. ${ }^{3}$ Pola berpikir sederhana ini membuat koalisi di masa lalu tidak pemah mampu bertahan lama. Tidak jarang sebuah pemerintahan hanya bertahan selama beberapa bulan. Sehingga dalam jangka waktu 9 tahun (dari1950 hingga 1959) terjadi 7 kali pergantian kabinet. ${ }^{4}$ Dengan kata lain setiap kabinet hanya berusia rata-rata 1,2 tahun, sebuah jangka waktu yang teramat pendek untuk mengevaluasi kebijaksanaan.

Pergantian kabinet yang sedemikian cepat pun bukan hanya partai-partai kesulitan membangun budaya koalisi namun juga mendorong ABRI untuk kemudian menciptakan koalisi dengan Sukarno untuk menggusur partai politik dari eksekutif lewat demokrasi terpimpinnya. Pengalaman ini sangat penting untuk dingat partai-partai saat ini karena ancaman ototerisme dan militerișme tidak dengan sendiri-nya hilang dengan lengsemya Suharto. Sebab peninjauan kernbali oleh kekuatan status quo átas kinerja partai-partai oposisi dewasa ini dan kegagalan mereka menciptakan pemerintahan kelak dikemudian hari bukan tidak mungkin mengundang kembali status quo plus militer ke dalam kancah politik.

Sekalipun yang paling mendesak untuk dipahami adalah bahwa kesalahan utama dari model koalisi lama adalah bahwa model-model tersebut tidak dibangun diatas pemahaman ideologi partai yang menjadi salah satu pendorong utama kehidupan partai politik bersangkutan. Dengan kata-kata lebih sederhana dapatlah disimpulkan bahwa pada waktu itu koalisi tidak dibangun dengan landasan teori yang kuat sehingga menyulitkan masing-masing partai untuk menyusun kerjasama dengan rekanan me-

3 Tentang aliran ini baca Herbert Feith, "Pengantar," dalam Pemikiran Polilik Indonesia 1945-1965, diedit oleh Herbert Feith

${ }^{4}$ Rusadi Kantaprawira, Sistem Politik indonesia: Sualu Model Pengantar, Bandung: Penerbit Sinar Baru,1988, hal. 150-151. 


\section{Topik: Memberdayakan Partai Politik dalam Era Multipartai, Bambang Cipto}

reka masing-masing.

Teori koalisi terbagi ke dalam dua bagian besar, yakni, office-seeking model dan policy-seeking model. ${ }^{5}$ Dalam model pertama partai-partai bergabung semata-mata karena mereka ingin mendapatkan kekuasaan di pemerintahan. Dalam konteks ini partai-partai yang tidak pivotal, yakni partai yang tidak memenuhl syarat dan tidak diperlukan, tidak akan bergabung. Dengan kata lain, partai-partai hanya membatasi diri pada partai yang memang memiliki bargaining position yang sangat kuat. Sementara dalam model kedua, partai-partal bergabung karena mempertimbangkan keselarasan kebijaksanaan partai. Sehingga partai bergabung tidak sekedar merebut jabatan publik namun juga sangat rnempertimbangkan arah kebijaksanaan partai-partai yang akan berekanan dalam koalisi.

Arend Lijphart dengan elaborasi yang lebih rinci pada dasamya juga mengajukan dua baglan besar teori-teori koalisi. ${ }^{6}$ Bagian pertama terdiri dari teori minimal winning coalition, minimum size coalition, bargaining position. Teori-teori ini pada dasamya mengedepankan pentingnya unsur kehendak untuk mendapatkan kekuasaan sebesar-besarnya dari setiap partai yang akan bergabung ke dalam koalisi. Artinya motivasi politisi untuk berkoalisi tidak leblh dari usaha mendapatkan kekuasaan lewat pembentukan koalisi.

Bagian kedua adalah teori minimal range coalition, dan minimal connected winning coalition. Bagian kedua ini lebih mengetengahkan kedekatan ideologi dan kebijaksanaan sebagai dasar untuk membangun sebuah koalisi. Masing-masing elit didorong oleh motivasi kuat bahwa mereka berkoalisi karena pertimbangan kedekatan ideologi dan arah kebijaksanaan partai.

Secara khusus Lijphart menegaskan bahwa teori minimal range dan minimal connected winning adalah teori yang paling banyak diterapkan negara-negara demokrasi di dunia. Kelompok pertama jarang diterapkan dalam dunia nyata karena berdasarkan teon-teori ini partai, dengan motivasi tunggal mendapatkan kekuasaan politik (memaksimalkan kekuasaan politik), mengabaikan sama sekali pertimbangan ideologis dan kedekatan kebijakan politik. Sehingga tidak jarang partai dari spektrum kiri berkoalisi dengan partai dari spektrum kanan. Dengan kata lain, Lijphart hendak mengingatkan bahwa adalah sangat bijak bila partal politik hanya berkoalisi dengan partai lain yang masih dalam sebuah spektrum ideologi. Koalisi lintas spektrum ideologi sangat riskan karena akan menumbuhkan konflik ideologi dan kebijaksanaan.

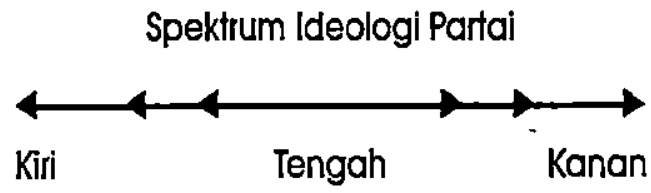

Lijphart membelah partai kedalam spektrum ideologi kiri, tengah, dan kanan. Semakin ke kanan maka partai-partai berada pada posisi sangat liberal (ekstrim kanan), semakin ke tengah semakin moderat. Sebaliknya semakin ke kiri sebuah partai akan semakin sosialis, komunistis (ekstrim kiri). Partai tengah adalah partai moderat yang dapat bergabung dengan kedua spektrum ideologi. Partal-partai yang berada pada spektrum ideologi kanan (demokrat, ijberal) sebaiknya bergabung dengan partai yang segaris atau berada disebelah kanan partai tengah (moderat). Sebaliknya partaipartai yang hidup dalam spektrum ideologi

5 Junko Kate and Michael Laver, 'Theory of Government Formation and the 1996 General Election in Japan," Party Politics, Vol. 4, 1998, hal. 23 1-23 4.

${ }^{6}$ Lipjhart, Op cit, hal52. 
kiri (demokrat, sosialis) sangat disarankan untuk berkoalisi dengan partal lain yang berada pada spektrum yang sama kalau tidak berjauhan. Dengan demikian koalisi antar partai yang berada di sebelah kanan dan di sebelah kiri sudah tentu sangat riskan karena masing-masing elit akan dipaksa melakukan kompromi ideologi yang berleblhan.

Ketentuan dasar dari spektrum ideologi inilah yang menjadi pedoman partai-partal politik di Jerman, Perancis, Belanda, Jepang dan negara-negara multipartai lainnya. Di negara-negara tersebut peluang partai melakukan koalisi lintas ideologi nyaris mendekati angka nol. Di Jerman memang pernah dicoba koalisi antara CDU (partai kanan) dan SDP (partai kiri) namun eksperimen ini berlangsung sesaat dan saat itu tidak pemah ada lagi upaya melakukan koalisi lintas ideologi. Demikian pula di Perancis model koalisi lintas ideologi yang disebut kohabitasi inipun berakhir dengan kegagalan. Sejak itu negara-negara multipartai hanya menerapkan teori satu lingkungan ideologi, baik kanan maupun kiri sebagai strategi dalam menyusun koalisi. CDU selaku partai kanan tak lagi pemah berkoalisi dengan partai kiri SDP. Perlu pula dicatat disini bahwa SPD tidak pernah ragu membawa bendera partai kiri karena pada umumnya makna kiri di Eropa dan di negara demokrat lain telah berubah -menjadi sangat moderat dan cenderung dekat dengan partai tengah. Itulah sebabnya dewasa ini Eropa didominasi oleh partai-partai kiri dan tidak pemah ada kekhawatiran bahwa Eropa akan jatuh ke dalam pengaruh komunis Rusia atau Eropa Tiniur.

Sejauh mana Indonesia dapat mengapresiasi perkembangan diatas adalah persoalan paling krusial bagi masa depan sistem multipartai kita. Jika pola berpikir diatas dianggap tabu karena berbagai alasan maka kemungkinan reformasi justru akan berlangsung lambat. Sudah tentu penulis tidak menolak kenyataan bahwa diperlukan adaptasi agar teori tersebut dapat segera diaplikasikan ke bumi Indonesia. Namun kenyataan bahwa semua sistem multipartai menerapkan metode diatas menjadi keharusan bagi elit partai untuk memikirkan sungguh-sungguh opsi diatas.

\section{Hubungan Eksekutif-Legislatif}

Bagaimana seharusnya hubungan eksekutif-legislatif dalam era multipartai? Persoalan ini cukup krusial akan menentukan masa depan sistem multipartai dan pada gilirannya masa depan Indonesia baru kita. Persoalan ini lebih banyak menyangkut isu kelembagaan daripada sekedar relasi antara dua cabang pemerintahan.

Ada semacam konvensi tak tertulis bahwa sistem multipartai akan menghasilkan badan legislatif yang terdiri dari banyak partai. Kecuali ada sebuah partai sangat dominan atau karena campur tangan berlebihan, maka pemilihan dalam sistem multipartal bisa diperkirakan akan menghasilkan parlemen atau badan legislatif dengan jumlah partal yang banyak. Itulah sebabnya diperlukan koalisi untuk mendirikan pemerintahan. Sistem pemilihan proporsional, yang dimaksud untuk memelihara sistem multipartal dengan sendirinya akan memberi jatah kursi bagi partai pemenang pemilu sesuai dengan proporsi suara yang berhasil dikumpulkan oleh masing-masing partai bersangkutan. Dengan sendirinya sistem multipartai mengisyaratkan perlunya. pemerintahan koalisi karena perolehan suara masing-masing partai biasanya sangat sedikit (dibawah $50 \%$ ) dalam arti tidak cukup untuk memenuhi persyaratan mayoritas.

Koalisi yang dibentuk sebagai hasil pemilihan multipartai secara alamiah dan normal akan menghasilkan seorang Perdana 
Menteri sebagal pucuk pimpinan pemerintahan (head of government). Sepanjang eksperimen demokrasi liberal dalam era 50 an Indonesia pun memiliki beberapa Perdana Menteri. Dengan kata lain, koalisi di masa lalu ditinjau dari sudut kepala eksekutif sebenamya sangat alamiah dan normal.

Persoalan sekarang adalah bahwa konstitusi menyatakan presiden sebagal kepala eksekutif dan dipilih oleh MPR. Ini berarti bahwa parlemen multipartal tidak menelorkan Perdana Menteri namun menghasilkan presiden. Persoalan ini sangat merepotkan bagi perkembangan multipartai mendatang. Tiga kemungkinan buruk yang akan muncul karena kesalahan institusional, yakni, presiden tetap dipilih oleh MPR. Pertama, presiden akan menjadi sangat otoriter karena dipilih oleh MPR yang sebagian anggotanya tidak dipilih langsung oleh rakvat (vertically unaccountable). Secara konstitusional presiden keempat mendatang dengan demikian hanya bertanggungjawab kepada MPR. Jika kekuasaan presiden kemudian membengkak secara tak terkontrol atau bahkan melakukan abuse of power maka ia dapat melempar kesalahan tersebut kepada MPR bukan kepada dirinya sendiri. Secara teknis-konstitusional rakyat tidak dapat menghukurn presiden karena memang tidak dipilih oleh rakyat. Kedua, jika presiden dianggap menyimpang dari ketentuan yang disepakati partai-partal di DPR sedangkan partai-partai tidak mungkin menghentikan presiden karena ada unsur utusan daerah dan golongan serta ABRI yang tidak dipilih rakyat maka terdapat kemungkinan DPR akan mengalami keretakan. Jika ini terjadi maka bukan tidak mungkin akan terjadi deadlock dalam hubungan eksekutif-legislatif Jika perkiraan ini terjadi maka pemerintah akan mengalami keguncangan karena tidak didukung lagi oleh DPR padahal DPR sulit menja- tuhkan presiden. Perkiraan ini akan membuat pemerintah secara keseluruhan mengalami kelumpuhan politik. Sudah barang tentu keadaan ini akan memperburuk upaya memperbaiki krisis ekonomi. Ketiga, jika kombinasi multipartai dan presiden ini tetap dipaksakan maka daya tahannya akan sangat rendah. Sebuah penelitian mutakhir menghasilkan sebuah kalkulasi bahwa kombinasi buruk ini akan menghasilkan pemerintahan dengan daya tahan paling lama 11 tahun sebelum ambruk untuk digantikan oleh pemerintahan otoriter. ${ }^{7}$

Berbeda dengan sistem multipartai seperti di Jepang yang dapat derigan mudah menggantikan Perdana Menteri jika tidak lagi didukung oleh parlemen Jepang. Di Jepang pemerintah dapat tetap berjalan sekalipun Perdana Menteri digantikan. Sedangkan di Indonesia kelumpuhan pemerintah benar-benar akan memperburuk krisis ekonorni nasional. Persoalan ini sudah barang tentu tidak mudah dipecahkan kecuali dengan melakukan perubahan undang-undang atau merevisi konstitusi untuk disesuaikan dengan tuntutan reformasi saat ini.

\section{Isu Penegakan Supremasi Sipil}

Tantangan terberat yang barangkall akan dihadapi sistem multipartai dalam jangka pendek maupun jangka panjang adalah bagaimana menegakkan kembali supremasi sipil yang sempat tumbuh dalam era demokrai liberal dimasa lalu. Selama supremasi militer atas sipil masih menjadi realita politik maka selama itu pula multipartai tidak akan pernah sungguh-sungguh tertembagakan. Itu berarti bahwa selama konsep dwi-fungsi ABRI masih bercokol di Indonesia maka supre-

7 Adam Przeworski, Nfichael Alvarez, Jose Antonio Cheibub \& Femando Limongi, "What Makes Democracies Endure," Journal ofdemocracy, (January 1996). 
masi sipil akan tetap menjadi impian.

Inilah agenda yang tersulit yang bakal dihadapi elit partai dalam era multipartai saat ini. Serangkaian peristiwa kekerasan akhirakhir ini memperkuat keyakinan publik bahwa kekerasan politik warisan Orde Baru yang sangat mengandálkan kontribusi ABRI ternyata menimbulkan dampak sangat berbahaya yang pada ujung-ujungnya sulit dijinakkan.

Ada dua pandangan menarik berkenaan dengan masa depan hubungan șipil militer di negara transisi. Pandangan pertama cenderung negatif dan meragukan kemampuan sipil mendorong kembali militer ke barak. ${ }^{8}$ Pandangan ini dikemukakan oleh Alfred Stepan, seorang pakar militer Brasil. Pandangan kedua cenderung positif dan mengajukan argumentasi bahwa peran politik militer sangat tergantung pada kapasitas sistem partai dan negara bersangkutan. Pandangan ini diajukan oleh Felipe Aguero seorang pakar militer Spanyol. ${ }^{9}$ '

Menurüt Stepan kesulitan utama negara-negara transisi dalam menggalang dukungan untuk mendorong militer keluar dari sistem politik adalah karena militer merasa memiliki hak istimewa dan cenderung melawan setiap kali sipil mencoba untuk mengurangi peran politik militer. Akibatnya adalah transisi politik demokratis diwamai dengan konflik kekerasan antara militer dan sipil dengan mengambil berbagal bentuk dan manifestasinya, baik transparan maupun tidak transparan. Konflik kekerasan inilah yang mengakibatkan reformasi berjalan sangat lambat dan militer tetap bertengger dalam puncak-puncak kekuasaan politik.

Aguero, sebaliknya, mengajukan sebuah argumentasi baru dengan mengambil Spanyol sebagai studi kasus. Tesis utama Aguero adalah bahwa peran politik militer pada dasamya dapat direduksi secara bertahap asalkan sejumlah persyaratan fundamental dapat dipenuhi. Persyaratan ter- sebut adalah kesediaan kekuatan sipil untuk selalu berdiri di depan dalam mengajukan proposal perubahan-perubahan politik dan kemampuan kekuatan sipil menggalang kekuatan gabungan untuk menghadapi militer yang sangat terorganisir (well-organized) dan kaya sumber daya (well-financed).

Bahkan Aguero bergerak lebih jauh dari Stepan dengan mengemukakan eksperimen Spanyol dan Uruguay bahwa sistem multipartai yang ideal adalah sistem multipartai yang sederhana, yakni, terdir! hanya beberapa partai besar yang mampu menandingi kinerja militer. Disini kita dapat belajar bahwa Brasil yang menerapkan sistem banyak partai, dari partai besar hingga partai gurem, temyata gagal mengundurkan militer. Sementara Uruguay dan Spanyol yang mengembangkan sistem partai sederhana tapi kokoh dan legitimate ternyata lebih cepat mengundurkan militer dari gelanggang politik.

Dengan menggabungkan kedua pendapat diatas maka kita dapat menarik kesimpulan bahwa persoalan dasar dari hubungan sipil-militer di negara-negara transisi menuju demokrasi adalah apakah negara tersebut memiliki sistem partal kuat,berpengaruh, serta legitimate. Dalam era reformasi argumen ini tampaknya cukup realistis dalam arti berkurangnya pengaruh otoritarianisme Orde Baru membuat upaya ke arah itu bukan sesuatu yang sekedar impian. Persoalannya adalah sejauh mana partai-partai baru dapat segera menyadari betapa penting menggalang kekuatan opo-

${ }^{6}$ Alfted Stepan, Militer dan Demokratisasi: Pengalaman Brasil dan Beberapa Negara Lain, Terjemahan,Jakarta: Grafiti Pers, 1996.

${ }^{9}$ Felipe Aguero, Soldiers, Civilians, and Democracy: Post-Franco Spairi in Comparative Perspective, Baltimore: The John Hopkins University Press, 1995. 
Topik: Memberdayakan Partai Politik dalam Era Multipartai, Bambang Cipto

sisi untuk menekan militer tanpa harus mempersoalkan harga diri militer.

Tulisan diatas dimaksudkan untuk menciptakan sebuah kondisi dialogis di kalangan kekuatan reformasi khususnya di kalangan politisi sipil. Sudut pandang tulisan ini cenderung memberikan kritikan tajam terhadap partai politik dengan maksud memberikan semacam gambaran masa kini dan masa depan yang tidak mudah. Sesual dengan usia gerakan reformasi dan partal-partal politik baru jelas bahwa masih terlalu banyak yang harus dan dapat dikerjakan oleh semua pihak. Secara khusus partai politik bakal menjadi pemain utama dalam pentas politik Indonesia baru mendatang. Mengingat politik dimasa depan akan cenderung lebih terbuka dan demokratis sudah layaklah kiranya jika calon pemegang kendali masa depan ini terbiasa berpikir realistis dan tidak sekedar memanfaatkan momen-momen jangka pendek. Partai politik diharapkan memikirkan perannya dalam konteks perjuangan reformasi jangka panjang yang sudah barang tentu berbeda dengan target pemilu yang hanya berjangka pendek. •.

\section{Daftar Pustaka}

Aguero, Felipe Soldiers, Civilians, and Democracy: Post-Franco Spain in Comparative Perspective, Baltimore: The John Hopkins University Press, 1995, Feith, Herbert "Pengantar," dalam Pemikiran Politik Indonesia 1945-1965, diedit oleh Herbert Feith dan Lance Castles, Jakarta: LP3ES, 1988.

Kantaprawira, Rusadi Sistem Politik Indonesia: Suatu Model Pengantar, Bandung:Penerbit Sinar Baru, 1988.

Kato, Junko and Michael Laver, "Theory of Government Formation and the 1996 General Election in Japan, ".Party Politics, Vol. 4, 1998.

Lijphart, Arend, Democracies: Patterns of Majoritarian and Consensus Government in Twenty-One Countries, New Haven: Yale University Press, 1984.

Power, Timothy J. "Puppets, Parties, and Paradoxs: Changing Attitude Toward Party Institutionalization in Post-Authoritarian Brazil," Party Politics, Vol. 3, (April, 1997).

Przeworski, Adam, Michael Alvarez, Jose Antonio Cheibub \& Femando Limongi, "What Makes Democracies Endure," Journal ofdemocracy, (January 1996). Stepan, Alfred Militer dan Demokrasi,: Pengalaman Brazil dan Beberapa Negara Lain, Terjemahan, Jakarta: Grafiti Pers, 1996. 